Revista Brasileira de Agricultura Irrigada v.11, nº.5, p. 1723 - 1731, 2017

ISSN 1982-7679 (On-line)

Fortaleza, CE, INOVAGRI - http://www.inovagri.org.br

DOI: $10.7127 /$ rbai.v11n500777

Protocolo 777.17 - 23/05/2017 Aprovado em 31/08/2017

\title{
LONG-TERM VALIDATION OF A MEMBRANE-BASED SUBSURFACE IRRIGATION SYSTEM
}

\author{
Valeria Ingrith Almeida Lima ${ }^{1}$, Bruce G. Sutton ${ }^{2}$, Pierre Le-Clech ${ }^{3}$, Gregory Leslie ${ }^{4}$, \\ Claudia Keitel ${ }^{5}$
}

\begin{abstract}
This experiment is part of a series of studies to select potential semi-permeable membranes to enable membrane-based sub-surface irrigation. Two commercially available membranes, NF and $\mathrm{RO}$, and an under-development FO-TFC membrane were used in a glasshouse trial for a complete growth cycle of common bean (Phaseolus vulgaris $c v$. Jade) on potable water $(0.3 \mathrm{dS} / \mathrm{m})$. For each of the membrane experimental units, water was delivered to plants through specially designed cross-flow subsurface irrigation cells. During the germination phase, membrane performance was evaluated by total percentage of germination, germination rate and mean germination time. Plant height and number of leaves were taken throughout the experiment. Fresh and dry weight of leaves and stem, along with stem diameter were measured at the end of the experiment. Analysis of leaf gas exchange further indicates the ability of the membrane-based irrigation system to meet crop water demand based on the effects of irrigation treatments on stomatal conductance. For all treatments, plants were able to reach reproductive maturity, with the best yield result observed for the FO-TFC membrane. This novel approach contributes to efforts to improve precision of irrigation water delivery as plants drive water across the membrane according to their evapotranspiration demand in both quantity and time.
\end{abstract}

Keywords: membrane technology, subsurface irrigation, water conservation.

${ }^{1} \mathrm{PhD}$ student, CAPES Foundation fellow, Ministry of Education of Brazil, Brasília - DF 70040-020, Brazil. UNESCO Centre for Membrane Science and Technology, School of Chemical Engineering, The University of New South Wales, Sydney 2052, Australia. Email: v.almeidalima@student.unsw.edu.au

${ }^{2}$ Honorary Professor, Sydney Institute of Agriculture, Faculty of Science at The University of Sydney and Visiting Fellow at UNSW, Sydney, Australia.

${ }^{3}$ Associate Professor, UNESCO Centre for Membrane Science and Technology, School of Chemical Engineering, The University of New South Wales, Sydney 2052, Australia.

${ }^{4}$ Professor and Director, UNESCO Centre for Membrane Science and Technology, School of Chemical Engineering, The University of New South Wales, Sydney 2052, Australia. g.leslie@unsw.edu.au

${ }^{5}$ Lecturer, School of Life and Environmental Sciences, The University of Sydney, Australia. 
Lima et al.

\title{
VALIDAÇÃO DE UM SISTEMA DE IRRIGAÇÃO SUBSUPERFICIAL BASEADO EM TECNOLOGIA DE FILTRAÇÃO POR MEMBRANA
}

\begin{abstract}
RESUMO
Este trabalho é resultado de uma série de estudos a fim de selecionar membranas semipermeáveis que possibilitem irrigação subsuperficial baseado em technologia de filtração por membrana. Duas membranas disponíveis comercialmente, nano-filtração (NF), osmose reversa (RO) e uma de osmose direta, FO-TFC em desenvolvimento, foram usadas em casa de vegetação durante o ciclo de desenvolvimento do feijão comum (Phaseolus Vulgaris $c v$. Jade), sendo utilizado água de abastecimento $(0.3 \mathrm{dS} / \mathrm{m})$ como fonte de irrigação. Para cada unidade experimental de irrigação por membranas, utilizou-se um módulo de irrigação subsuperficial a uma vazão de $1 \mathrm{l} / \mathrm{min}$, em vaso de dimensões 750x275mm, 20 sementes por vaso. O substrato usado é composto por 33\% de material orgânico, 33\% de areia lavada e 33\% de fibra de coco. Durante a fase de germinação, percentual total de germinação, taxa de germinação e tempo médio de germinação foram avaliados. Altura de planta e número de folhas foram medidas durante ao longo do experimento. Peso fresco e seco das folhas e caule, e diâmetro de caule foram medidos no final do experimento. A análise de trocas gasosas na folha complementa a investigação da habilidade do sistema de irrigação por membranas de satisfazer a necessidade hídrica da cultura. Para todos os tratamentos, as plantas alcançaram maturidade reprodutiva, sendo a melhor produtividade observada para a membrana FO-TFC. Esta tecnologia inovadora soma-se a esforços de aperfeiçoar a eficiência de aplicação da água de irrigação considerando que as plantas obtém água através da membrana em quantidade e intervalos definidos pela demanda evapotranspirativa da cultura.
\end{abstract}

Palavras-chave: tecnologia de membrana, irrigação subsuperficial, manejo de água.

\section{INTRODUCTION}

In order to meet the food demand of a growing population, expected to reach 9 billion people by 2050, the agricultural sector needs to increase productivity in $70 \%$ (FAO 2009). Increase in crop yield based on sustainable use of limited natural resources need to come from novel technologies and improvements of existing ones. Considering that over $70 \%$ of freshwater use goes to irrigation, the development of precision irrigation technologies that result in increased water utilization is greatly importance to guarantee future food security (Madramootoo 2015).

This paper is part of a series of studies on the utilization of semi-permeable membranes to compose a new subsurface irrigation system, which aims to improve precision of irrigation water delivery as plants drive water across the membrane according to their evapotranspiration demand in both quantity and time (Lima et al. 2016a; Lima et al. 2015; Lima et al. 2016b). In principle, the proposed membrane-based irrigation system exploits the spontaneous water movement through soil-plant-atmosphere continuum (SPAC) driven by photosynthesis; water moves across the membrane tube has been demonstrated to occur in response to the lower water potential created by both soil and plant on the outside. This paper discusses the performance of a nanofiltration, a reverse osmosis and a forward osmosis membrane based on their efficiency to deliver irrigation water during germination and growth of common bean.

\section{MATERIAL AND METHODS}

Two commercially available membranes, a nanofiltration (NF), a reverse osmosis membrane (RO) and an under development thin- 
film composite forward osmosis (FO-TFC) membrane were used in a glasshouse trial for a complete growth cycle of common bean (Phaseolus vulgaris $\mathrm{cv}$. Jade) on potable water $(0.3 \mathrm{dS} / \mathrm{m})$. For each of the membrane experimental units, water was delivered to plants through specially designed cross flow irrigation modules buried in a $750 \times 275 \mathrm{~mm}$ planter pot, at a flow rate of $1 \mathrm{~L} / \mathrm{min}$. A local standard soil mix was prepared from 33\% organic garden mix, 33\% washed river sand and 33\% Coco peat. Soil water was monitored using a ceramic thermal conductivity soil moisture sensor.

The Perspex cross-flow irrigation modules were manufactured to house membrane sheets on both sides of the water channels. A total of six experimental units were tested, two replicates for each membrane. Each experimental unit was composed of a membrane module, a $750 \times 275 \mathrm{~mm}$ planter pot, a 100L water reservoir, a magnetic drive pump (model MD-30RZ-220N), a flow meter, and sensors for salinity, temperature and water level inside each feed water tank. The system was left running for a week to reach differentiation among membrane treatments for soil moisture baseline, after which, 10 seeds were planted on each side of membrane module, three $\mathrm{cm}$ apart and $10 \mathrm{~cm}$ deep (Figure 1). a.

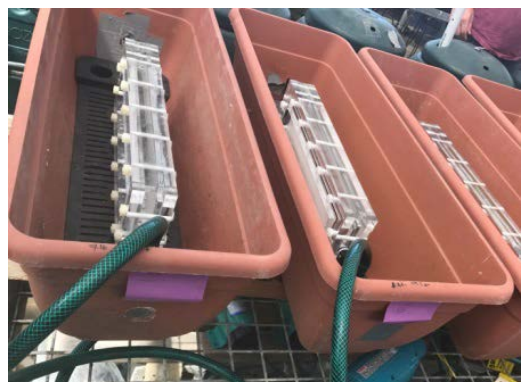

b.

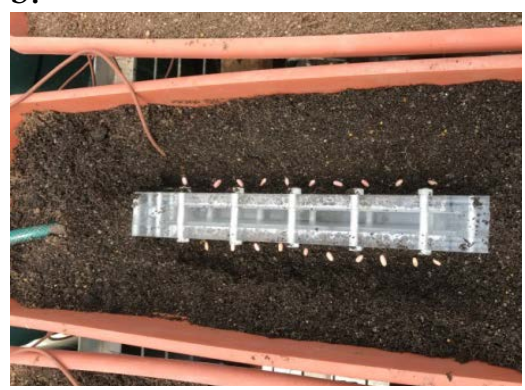

C.

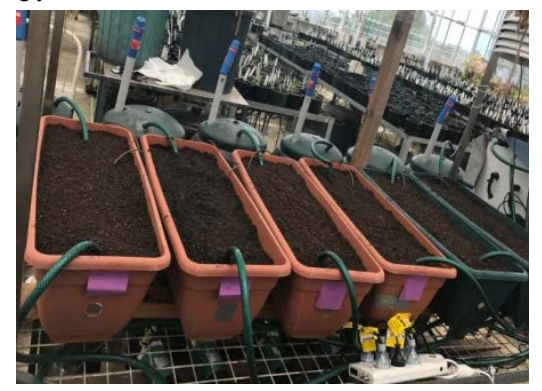

Figure 1. Installation of irrigation modules (a), seeds sowing (b), and final pot setup (c).

During the germination phase, the performance of membranes was evaluated by total germination percentage, germination rate, mean germination time and coefficient of uniformity. Plant height and number of leaves were taken throughout the experiment. Fresh and dry weight of leaves and stem, along with stem diameter were measured at the end of the experiment. Analysis of leaf gas exchange was performed using the LI-6400 XT Photosynthesis system (LI-COR, USA) by means of stomatal conductance $\left(g_{s}\right)$, transpiration $(E)$, carbon assimilation rate (A), and efficiency of open Photosystem II reaction centres ( $\mathrm{F}_{\mathrm{v}}{ }^{\prime} / \mathrm{F}_{\mathrm{m}}$ ', unitless). Means of seed germination indices and plant growth variables were compared by the t-test at a probability of 5\% using the ASSISTAT software (Silva \& Azevedo 2006).

\section{RESULTS AND DISCUSSION}

\section{Effect of membrane type on germination and seedling establishment}

Results for seed germination indices and seedling height at 15 days after sowing are summarized on Table 1. Visual appraisal of leaf area development after 15 days can be seen on Figure 2. For the germination percentage, no significant difference among membrane treatments was found. However, a significantly higher vigour of the FO-TFC sample in comparison to the RO membrane by a factor of 2 was found, indicated by higher germination rate; NF was found to be statistically equal to both FO-TFC and RO. No significant statistical difference was 
Lima et al.

observed among treatments for mean germination time, coefficient of uniformity of germination and average seedling height along establishment phase (15d).

Table 1 - Analysis of germination indices and average height for different membrane types

\begin{tabular}{|c|c|c|c|c|c|}
\hline \multirow{2}{*}{ Membrane type } & \multicolumn{4}{|c|}{ Germination } & \multirow{2}{*}{$\frac{\text { Seedling growth }}{\mathrm{SH}(\mathrm{cm})}$} \\
\hline & GP (\%) & GR & MGT & CUG & \\
\hline FO-TFC & $75 \mathbf{a}^{*}$ & $2.21 \mathbf{a}$ & $6.9 \mathbf{a}$ & $0.05 \mathbf{a}$ & $8.7 \mathrm{a}$ \\
\hline NF & $52.5 \mathbf{a}$ & $1.33 \mathbf{a b}$ & $8.2 \mathbf{a}$ & $0.04 \mathbf{a}$ & 7.9 a \\
\hline RO & $40 \mathbf{a}$ & 1.02 b & $8.2 \mathbf{a}$ & $0.03 \mathbf{a}$ & $5.5 \mathbf{a}$ \\
\hline
\end{tabular}

GP: germination percentage; GR: germination rate; MGT: mean germination time; CUG: coefficient of uniformity of germination; SH: seedling height; SLA: single leaf area.*Means followed by a common letter within same column are not significantly different by the t-test test at $5 \%$ probability

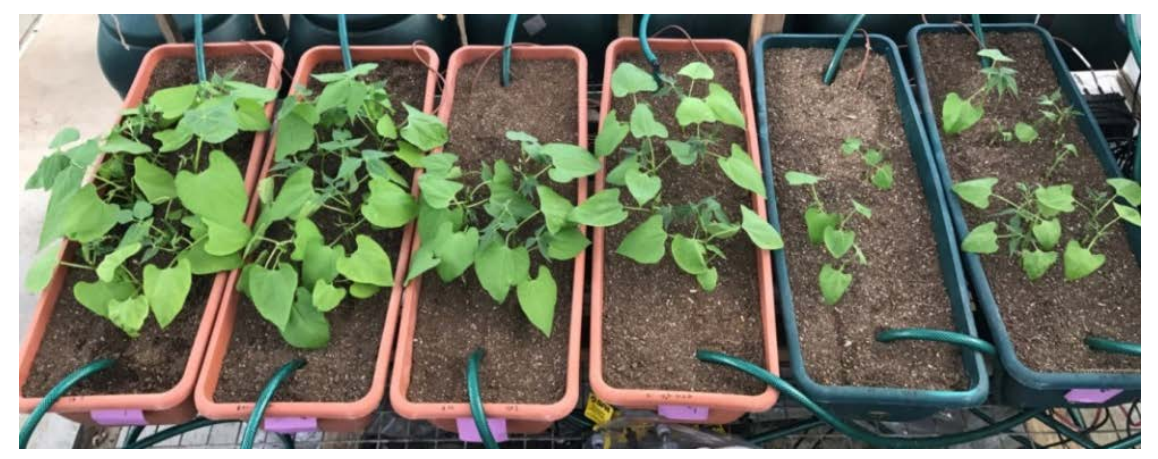

Figure 2. Visual appraisal of leaf area development 15 days after sowing for different membrane treatments, two replications each. From left to right, FO-TFC, NF and RO

\section{Effect of membrane type on crop vegetative growth}

A visual appraisal of plant growth for different membrane type and replications is depicted in Figure 3. A significant difference in plant height between treatments was only observed between the $20^{\text {th }}$ and $40^{\text {th }}$ day after sowing, for which the FO-TFC and the NF were statistically equal and superior to the RO membrane (Figure 3b). a.

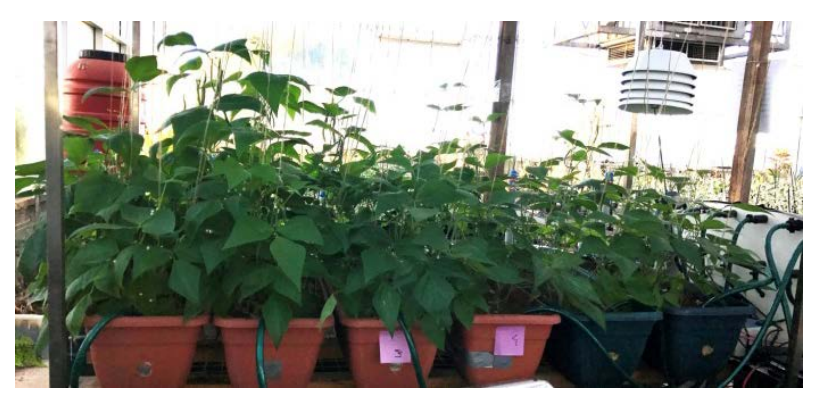

b.

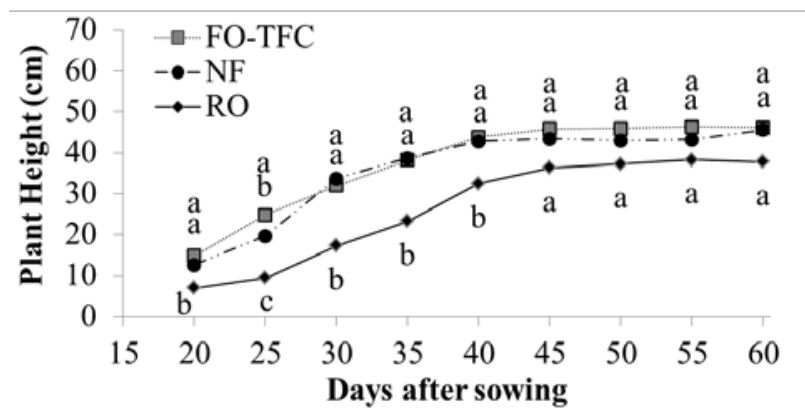

Figure 3. Visual appraisal of plant height at 43 days after sowing for different membrane treatments, two replications each. From left to right, FO-TFC, NF and RO (a) and Development of plant height after seedling establishment (b). * Means followed by a common letter for the same day are not significantly different by the t-test test at $5 \%$ probability 
A significant effect of membrane treatments was seen for total leaf biomass accumulation was evident (Figure 4a), for which the FO-TFC, equal to $20.1 \mathrm{~g}$ per tray, was statistically superior to both NF (8.6 g) and RO (6.2 g) by a factor of two and three, respectively. A highly linear positive correlation was found between leaf dry weight and accumulative water usage per treatment (Figure 4b), from which a transpiration index (slope) of $1.2 \mathrm{~g} / \mathrm{kg}$ water was observed. From that we can also observe that the consumption of water is not completely used for the production of biomass, as the regression (Figure 4b) crossed the origin at -1.57 , which might indicate that a small percentage of irrigation water is evaporating directly from the soil. The total water transport through the FO-TFC, NF and RO were averaged at 17.8, 7.8 and 7.1 liters, respectively. The pure water permeability for the respective membranes are 8.9 (Kim et al. 2017), 11.0 (Dang et al. 2014) , and 4.0 L.m ${ }^{-2} \mathrm{~h}^{-1} \operatorname{bar}^{-1}$ (Liu et al. 2011). If permeability was the sole contribution to membrane performance, a greater difference would be expected between the total volume of

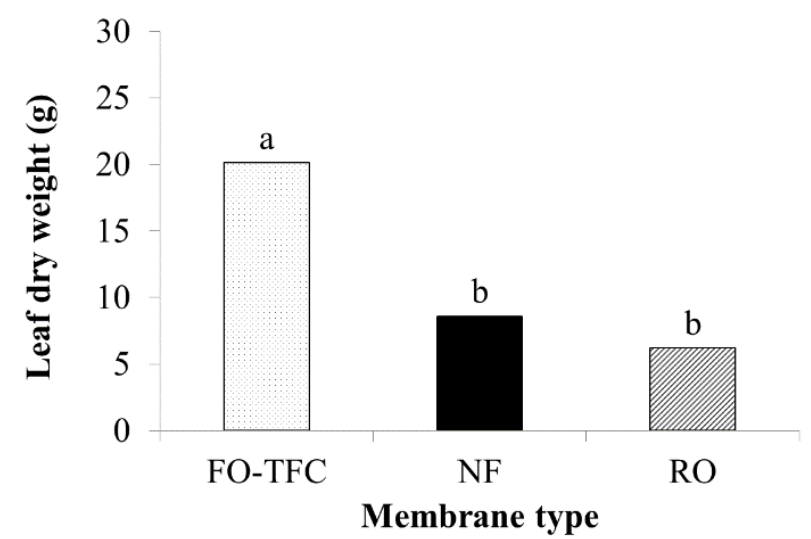

water delivered to plants between the RO and NF, which was not observed, suggesting that other membrane properties also affect water transport. The NF and the RO are both thin-film composite membranes, having the polyamide active layer on top of a polysulfone support, reinforced by a polyester layer (Freger et al. 2002). These support materials have been reported to negatively affect water flux by limited spontaneous wetting (McCutcheon \& Elimelech 2008); the wetting performance of each layer was accessed by their contact angle, found to be moderately hydrophilic $\left(<90^{\circ}\right)$ for the polysulfone, equal to $67.6^{\circ}$, and hydrophobic $\left(>90^{\circ}\right)$ for the polyester, equal to $95.2^{\circ}$. The FO-TFC is also characterized as a thinfilm composite with a polyamide coating (CSM 2016) on top of a support layer of non-identified material, however, scanning electron microscopy of the support layer revealed a highly porous finger-like structure, reported to increase performance of forward osmosis membranes by reducing the resistance of water path to the active layer (Tiraferri et al. 2011)

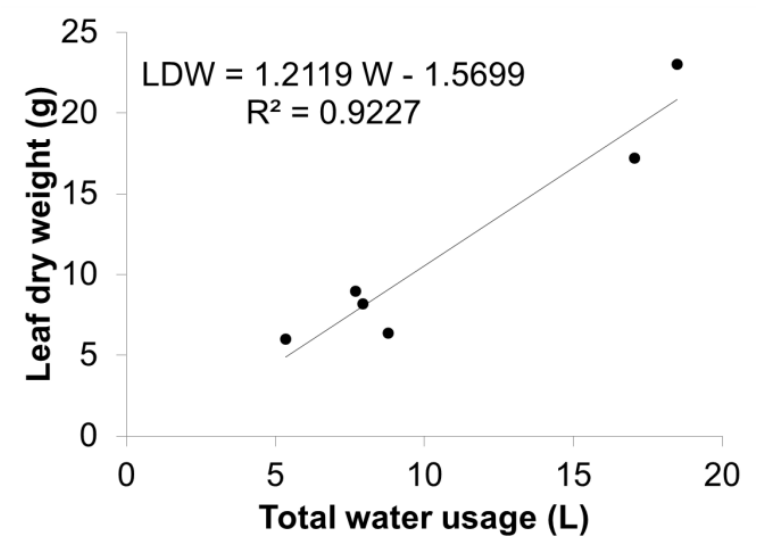

Figure 4. Analysis of leaf dry mass (a) and biomass accumulation by total water usage per tray (b) at the end of experiment for conditions of different membrane types

It was observed a significant effect of membrane treatment for the stem diameter (Figure 5a), total fresh and dry weight, as well as water content (Figure 5b). For the effect of membrane type on stem diameter, there was no significant statistical difference among treatments. However, it was found a significant effect of treatments for the total stem fresh weight, with the best results found for the FO-TFC membrane (93.3 g), followed by NF (45.2 g) and RO 28.9, both statistically equal; a similar statistical result was found for the total stem dry weight, were the FO-TFC produced a dry weight of $19.3 \mathrm{~g}$, higher than both NF (7.85 g) and RO (4.9 g). For the stem water content, the 
Lima et al.

highest (83\%) and lowest (79.45) results were found for the RO and FO-TFC, respectively, with the NF (82.6\%) statistically equal to both; the

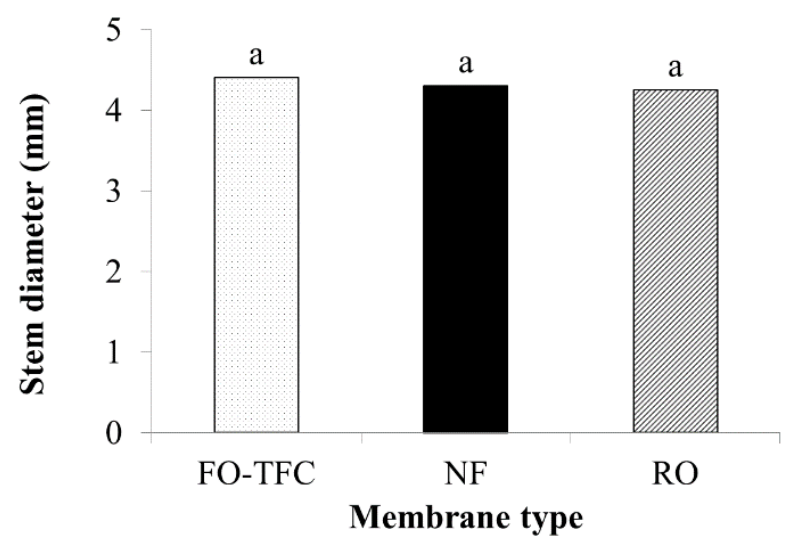

slight difference among treatments might be related to the effect of plant population on water availability (GP on Table 1).

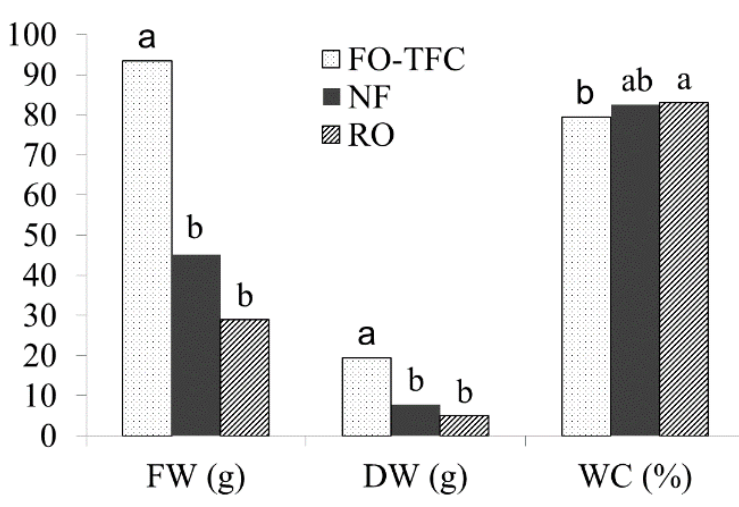

Figure 5. Analysis of stem diameter after 60 days of plant growth (a) and total fresh and dry weight along with water content of stem at the end of experiment (b) for conditions of different membrane types

\section{Effect of membrane type on leaf gas exchange}

Leaf gas exchange data, stomatal conductance $\left(\mathrm{g}_{\mathrm{s}}\right)$, transpiration $(\mathrm{E})$, carbon assimilation rate (A), and efficiency of open Photosystem II reaction centres $\left(\mathrm{Fv}^{\prime} / \mathrm{Fm}^{\prime}\right)$, is reported in Figure 6. Measurements of leaf gas exchange were taken on the $58^{\text {th }}$ day after sowing, for a total of 60 days cultivation. Membrane type significantly affected stomatal conductance, transpiration and carbon assimilation rate, for which the FO-TFC presented a significantly higher performance than both NF and RO. No significant effect of membrane type was found for $\mathrm{F}_{\mathrm{v}} / \mathrm{F}_{\mathrm{m}}$ '.

For stomatal conductance, a maximum value of $0.057 \mathrm{~mol} \mathrm{H}_{2} \mathrm{O} \mathrm{m}^{-2} \mathrm{~s}^{-1}$ was observed for the FO-TFC, which was higher than the NF (0.022) and RO (0.025) by a factor of 2.5 and 2.3, respectively. Stomatal conductance is directly influenced by the aperture of guard cells, which is regulated by a number of factors, including humidity, light intensity, temperature, osmotic potential and concentration of ions, such as potassium (McAinsh et al. 2007; Reichardt \& Timm 2014). In the presence of water stress, the balance between water uptake and water loss to the atmosphere affects the turgor pressure of guard cells. They can increased their volume due to water uptake by osmosis, and consequently, their degree of aperture, where adequately turgid cells have been observed to widely open even at high temperatures (Waggoner \& Zelitch 1965). Reduction of stomatal conductance has also been reported as a plant adaptation to reduce loss of water by transpiration during water stress as stomata conductance of cowpea beans was observed to increase as irrigation regime varied from 80 to $120 \%$ of evapotranspiration (ETc), reaching a maximum value of $0.4 \mathrm{~mol} \mathrm{H}_{2} \mathrm{O} \mathrm{m}^{-2} \mathrm{~s}^{-}$ at $120 \%$ ETc (Frade et al. 2015). Hence, a better water transport through the FO-TFC may have resulted in better cell turgidity, wider stomata aperture and higher stomatal conductance. The total water transport through the FO-TFC was higher than the NF and RO by a factor of 2.3 and 2.5 , respectively, suggesting that plants growing on the FO-TFC membrane were able to maintain a better water status which was evident in the higher stomatal conductance.

A similar statistical result to stomatal conductance was observed for transpiration and carbon assimilation rate, where the FO-TFC outstand the NF and RO membranes. This is an expected result as stomatal resistance, inverse of conductance, is in series to other resistances that limit diffusion of $\mathrm{CO}_{2}$ and transport of $\mathrm{H}_{2} \mathrm{O}$ in the 


\section{LONG-TERM VALIDATION OF A MEMBRANE-BASED SUBSURFACE IRRIGATION SYSTEM}

soil-plant-atmosphere continuum (Waggoner \& Zelitch 1965). When a plant is under stress and closes its stomata, $\mathrm{CO}_{2}$ supply is limited and carbon assimilation can be reduced (Baker 2008).

No significant difference between membrane treatments was found for $\mathrm{F}_{\mathrm{v}}{ }^{\prime} / \mathrm{F}_{\mathrm{m}}$ ', an indication of a plant's tolerance to environmental stress (Murchie \& Lawson 2013; Zhou et al. 2017). $F_{v}$ ' is a variation in fluorescence from $F_{0}$, minimum fluorescence when all reactions centers are open by being exposed to a low intensity light, to $F_{m}$ ', maximum fluorescence when the acceptors are saturated by a light pulse. A reduced number of open reaction centers are expected for stressed plants, leading to a high fluorescence during $\mathrm{F}_{\mathrm{o}}$, which will lower $\mathrm{F}_{\mathrm{v}}{ }^{\prime} / \mathrm{F}_{\mathrm{m}}$ ' accordingly. In principle,
Photosystem II is the most vulnerable part of photosynthesis to environmental stress, where energy absorbed from light by chlorophyll reaction centers is used on the transmission of electrons to specific receptors participants in the production of ATP and reduction of NADP, this light usage path is called photochemical quenching, essential for the production of glucose. If electron transmission to receptors is inhibited, energy can be re-emitted as light (fluorescence) or heat (Maxwell 2000; Baker 2008), named nonphotochemical quenching. No significant difference on fluorescence changes indicates no effect of membrane type on the overall physiological capacity of plants to perform photosynthesis (Maxwell 2000). a

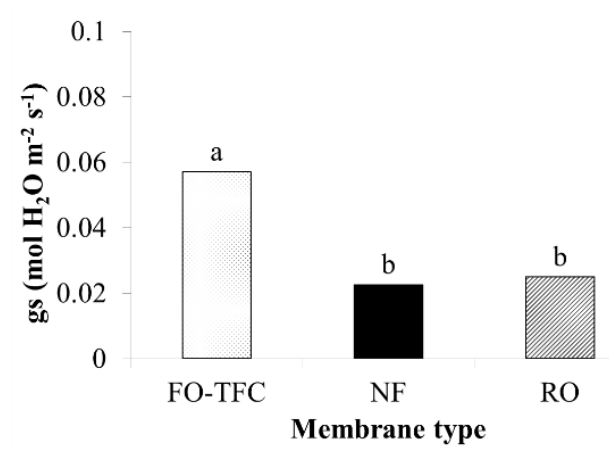

C

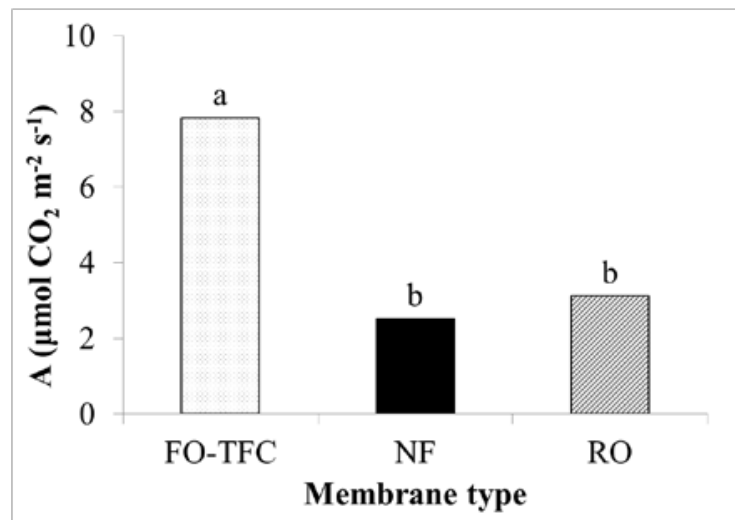

b

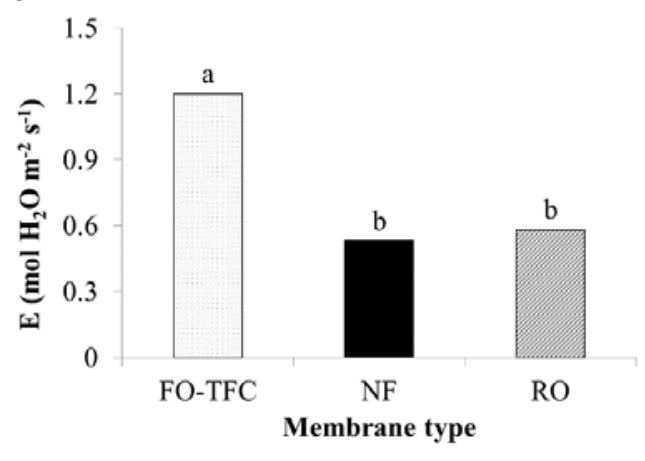

d

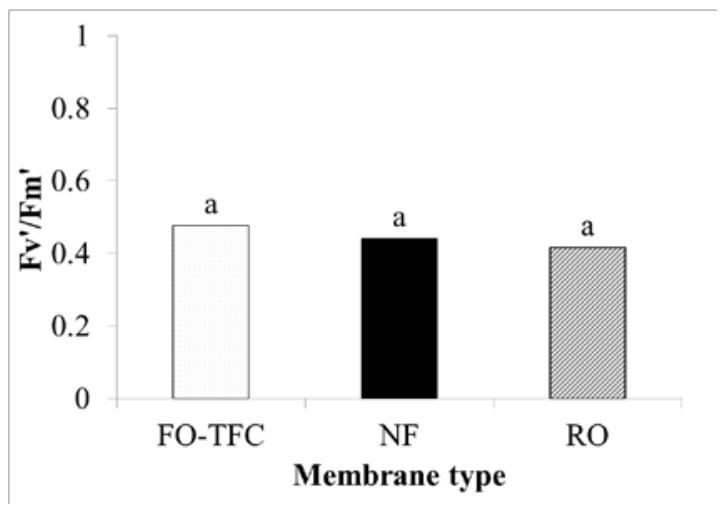

Figure 6. Leaf gas exchange by means of carbon assimilation rate, A (a), transpiration, E (b), stomatal conductance, $\mathrm{g}_{\mathrm{s}}(\mathrm{c})$ and efficiency of open Photosystem II reaction centres, $\mathrm{F}_{\mathrm{v}}{ }^{\prime} / \mathrm{F}_{\mathrm{m}}{ }^{\prime}$ unitless (d) 


\section{CONCLUSIONS}

The membrane based irrigation system has proved able to sustain irrigation water supply during a complete growth cycle of common bean as all treatments' plants reached reproductive phase. The FO-TFC membrane presented the best results for plant growth, such as leaf dry mass, and leaf gas exchange parameters, including stomatal conductance, carbon assimilation rate and transpiration. Considering those variables as a direct response of plants to water transport, the FO-TFC membrane was selected to be further studied in future complete crop life cycle trials.

\section{ACKNOWLEDGMENTS}

The authors acknowledge the Brazilian Ministry of education - CAPES foundation for providing the $\mathrm{PhD}$ scholarship.

\section{REFERENCES}

BAKER, N.R. Chlorophyll Fluorescence: A Probe of Photosynthesis In Vivo. Annual Review of Plant Biology, v. 59, n. 1, p. 89-113, 2008.

CSM, 2016. Data Sheet CSM Forward Osmosis Membrane. , p.1.

DANG, H.Q., PRICE, W.E. \& NGHIEM, L.D. The effects of feed solution temperature on pore size and trace organic contaminant rejection by the nanofiltration membrane NF270. Separation and Purification Technology, v. 125, p.43-51, 2014.

FAO. How to Feed the World in 2050. Report. Rome, 2009,

FRADE, L. J. G.; BRITO, M. E. B.; MOREIRA, R. C. L.; SILVA, L. DE A.; FERREIRA, I. B.; OLIVEIRA, I. M. Trocas gasosas em feijão caupi paulistinha sob lâminas de irrigação. In Inovagri International Meeting, 3, Fortaleza. Anais...
Fortaleza: Institute for Research and Innovation in Irrigated Agriculture, p. 7, 2015.

FREGER, V., GILRON, J. \& BELFER, S. TFC polyamide membranes modified by grafting of hydrophilic polymers: an FT-IR/AFM/TEM study. Journal of Membrane Science, v. 209, n. 1, p.283-292, 2002.

KIM, J.; BLANDIN, G.; PHUNTSHO, S.; VERLIEFDE, A.; LE-CLECH, P.; SHON, H. Practical considerations for operability of an 8" spiral wound forward osmosis module: Hydrodynamics, fouling behaviour and cleaning strategy. Desalination, v. 404, p.249-258.

LIMA, V. I. A.; LE-CLECH, P.; LESLIE, G.; SUTTON, B. G. In-situ desalination for climateresilient irrigation. Water e-Journal, v.1, n. 3, p.1-4, 2016a.

LIMA, V. I. A.; ANTONY, A.; LE-CLECH, P.; LESLIE, G.; SUTTON, B. G. New method for subsurface irrigation to improve use of brackish water. In Inovagri International Meeting, 3, Fortaleza. Anais...Fortaleza, Institute for Research and Innovation in Irrigated Agriculture, 2015, p. 1-9.

LIMA, V. I. A.; LE-CLECH, P.; LESLIE, G.; SUTTON, B. G,. Performance of a membranebased irrigation system for different evaporative conditions. In ASABE Annual meeting, Orlando. Anais... Orlando: American Society of Agricultural and Biological Engineers, 2016b, p. 2-8.

LIU, M.; LÜ, Z.; CHEN, Z.; YU, S.; GAO, C. Comparison of reverse osmosis and nanofiltration membranes in the treatment of biologically treated textile effluent for water reuse. Desalination, v. 281, n.1, p.372-378, 2011.

MADRAMOOTOO, C.A., 2015. Managing water for food security. Resource Magazine, v. 
20, n. 2, p.11-11.

MAXWELL, K. Chlorophyll fluorescence--a practical guide. Journal of Experimental Botany, v. 51, n. 345, p.659-668, 2000.

MCAINSH, M.R., MANCUSO, S. \& SHABALA, S. Calcium Oscillations in Guard Cell Adaptive Responses to the Environment. In S. MANCUSO \& S. SHABALA. Rhythms in Plants. p. 135-155, 2007.

MCCUTCHEON, J.R. \& ELIMELECH, M. Influence of membrane support layer hydrophobicity on water flux in osmotically driven membrane processes. Journal of Membrane Science, v. 318, n. 1-2, p.458-466, 2008.

MURCHIE, E.H. \& LAWSON, T.. Chlorophyll fluorescence analysis: A guide to good practice and understanding some new applications. Journal of Experimental Botany, v. 64, n. 13, p. 3983-3998, 2013.

SILVA, F. \& AZEVEDO, C. A New Version of The Assistat-Statistical Assistance Software. In WORLD CONGRESS ON COMPUTERS IN AGRICULTURE, 4., Orlando.
Anais...Orlado: American Society of Agricultural and Biological Engineers, 2006, p. 393-396.

REICHARDT, K. \& TIMM, L.C. Soil, Plant and Atmosphere 2nd ed. Barueri: Editora Manole, 2014, 478p.

TIRAFERRI, A.; YIP, N.; PHILLIP, W. A.; SCHIFFMAN, J. D.; ELIMELECH, M. Relating performance of thin-film composite forward osmosis membranes to support layer formation and structure. Journal of Membrane Science, v. 367, n. 1-2, p. 340352, 2011.

WAGGONER, P.E. \& ZELITCH, I.. Transpiration and the stomata of leaves. Science, v. 150, n. 3702, p.1413-1420, 1965.

ZHOU, R.; YU, X.; OTTOSEN, C.; ROSENQVIST, E.; ZHAO, L.; WANG, Y.; YU, W.; ZHAO, T.; WU, Z. Drought stress had a predominant effect over heat stress on three tomato cultivars subjected to combined stress. BMC Plant Biology, v. 17, n. 1, p. 24, 2017. 